\title{
PELATIHAN TEKNIK KOMUNIKASI SEBAGAI UPAYA PENCEGAHAN DAN PENATALAKSANAAN HIVIAIDS
}

\author{
Dewi Ambarwati1), Wilis Dwi Pangesti ${ }^{1)}$ \\ 1)Program Studi Kebidanan Program Sarjana, Fakultas Ilmu Kesehatan, Universitas Muhammadiyah Purwokerto, Purwokerto, \\ Jawa Tengah, Indonesia \\ Corresponding author : Dewi Ambarwati \\ E-mail : dwambarwt@gmail.com
}

Diterima 14 Oktober 2020, Direvisi 03 November 2020, Disetujui 03 November 2020

\begin{abstract}
ABSTRAK
Human Immunodeficiency Virus/Acquired Immunodeficiency Syndrom (HIV/AIDS) merupakan salah satu masalah kesehatan di Indonesia termasuk di wilayah kabupaten Banyumas, Jawa Tengah. HIV/AIDS merupakan penyakit menular yang menyerang sistem kekebalan tubuh. Infeksi tersebut menyebabkan penderita mengalami penurunan ketahanan tubuh sehingga sangat mudah untuk terinfeksi berbagai macam penyakit lain. Sebelum memasuki fase AIDS, penderita terlebih dahulu dinyatakan sebagai HIV positif. Sejak bulan januari-juni tahun 2018 ditemukan kasus baru sebanyak 123 kasus. Sedangkan jumlah kasus komulatif sejak ditemukannya HIVIAIDS pada tahun 1993 hingga tahun 2018 sebanyak 1.146 kasus. Data kasus di Banyumas ini berasal dari laporan VCT (Voluntery Councelling and Test) dari Rumah sakit Prof. Margono Soekardjo dan RSUD Banyumas. Dalam aktivitas pencegahan dan penagguangan HIVIAIDS diperlukan strategi komunikasi. Karena strategi komunikasi merupakan salah satu aspek keberhasilan program pencegahan dan penanggulangan HIVIAIDS. Strategi komunikasi yang dilakukan oleh Pemerintah Kabupaten Banyumas belum memberikan pengaruh pada paradigma dikalangan masyarakat tentang HIVIAIDS. Sehingga tujuan dilakukannya pelatihan pada mitra adalah sebagai upaya meningkatkan kemampuan tehnik komunikasi tentang HIVIAIDS pada mitra dan penyebaran leaflet tentang pencegahan dan penatalaksanaan HIVIAIDS pada mitra. Hasil dari pelaksanaan pelatihan pada mitra didapatkan terdapat peningkatan pengetahuan dan teknik komunikasi. Metode yang digunakan dalam pelatihan meliputi ceramah, tanya jawab, diskusi dan penayangan video. Tahapan kegiatan dimulai dengan icebraking, pretest, penyampaian materi, praktik ketrampilan dan ditutup dengan posttest.
\end{abstract}

Kata kunci: pelatihan; teknik komunikasi; HIVIAIDS

\begin{abstract}
Human Immunodeficiency Virus / Acquired Immunodeficiency Syndrome (HIV / AIDS) is one of the health problems in Indonesia, including in the Banyumas district, Central Java. HIV / AIDS is an infectious disease that attacks the immune system. The infection causes the patient to experience a decrease in body resistance so that it is very easy to become infected with various other diseases. Before entering the AIDS phase, the patient must first be declared HIV positive. Since January-June 2018, 123 new cases were found. Meanwhile, the number of cumulative cases since the discovery of HIV / AIDS in 1993 to 2018 was 1,146 cases. The case data in Banyumas comes from the VCT (Voluntery Councelling and Test) report from Prof. Hospital. Margono Soekardjo and Banyumas Hospital. In HIV / AIDS prevention and control activities, a communication strategy is needed. Because the communication strategy is one aspect of the success of the HIV / AIDS prevention and control program. The communication strategy carried out by the Banyumas Regency Government has not yet influenced the paradigm among the community regarding HIV / AIDS. So that the aim of conducting training for partners is as an effort to improve communication technical skills on HIV / AIDS to partners and to distribute leaflets on HIV / AIDS prevention and management to partners. The results of the implementation of training on partners found that there was an increase in knowledge and communication techniques. The methods used in the training include lectures, question and answer, discussion and video viewing. The activity stages began with icebraking, pretest, delivery of material, practice skills and closed with a posttest.
\end{abstract}

Keywords: training; communication techniques; HIV / AIDS 


\section{PENDAHULUAN}

Human

Immunodeficiency

Virus/Acquired Immunodeficiency Syndrom (HIVIAIDS) merupakan salah satu masalah kesehatan di Indonesia termasuk di wilayah kabupaten Banyumas, Jawa Tengah. HIVIAIDS merupakan penyakit menular yang menyerang sistem kekebalan tubuh. Infeksi tersebut menyebabkan penderita mengalami penurunan ketahanan tubuh sehingga sangat mudah untuk terinfeksi berbagai macam penyakit lain. Sebelum memasuki fase AIDS, penderita terlebih dahulu dinyatakan sebagai HIV positif. (Riani et al., 2016). Pada tahun 2016, kasus HIV di Jawa Tengah mencapai 1.867 kasus. Angka ini lebih tinggi dibandingkan dengan penemuan kasus HIV tahun 2015 yaitu sebanyak 1.467 kasus. Penderita HIVIAIDS berdasarkan umur terbanyak pada umur 25-49 tahun sebesar $67,33 \%$ yang merupakan usia reproduktif, umur $20-24$ tahun sebesar $16,01 \%$, dan umur di atas 50 tahun 9,48\%. Kasus penderita AIDS sendiri sebanyak 1.402 kasus, lebih banyak dibanding tahun 2015 yaitu 1.296 kasus. Berdasarkan kelompok umur, jumlah kasus berturut- turut, sebagai berikut: umur 2549 tahun sebesar $71,90 \%$, umur 50 tahun sebesar $15,41 \%$ dan umur $20-24$ tahun $8,2 \%$ (Tengah, 2019) (Kemenkes RI, 2018).

Pada penelitian lain didapatkan pengetahuan HIVIAIDS pada remaja mayoritas dalam kategori kurang yaitu 48,9\%. Presentasi remaja yang mampu menjawab dengan benar pengetahuan HIVIAIDS hanya sebesar 0,3\%. Minimnya informasi tentang HIVIAIDS yang diperoleh menjadi salah satu faktor kurangnya pengetahuan HIVIAIDS pada remaja (Siswanto, 2010).

Selain remaja, penularan HIVIAIDS dari ibu hamil ke bayi merupakan kasus yang perlu diperhitungkan. Prevalensi ibu hamil positif HIV mencapai $0,38 \%$, sedangkan ibu hamil yang positif HIV sebanyak 15.517 kasus. Pendekatan yang digunakan dalam pencegahan dan penatalaksanaan HIVIAIDS pada kasus ini tentu berbeda dengan kasus pada remaja. Kasus HIVIAIDS pada ibu hamil tidak cukup dilakukan penatalaksanaan dengan peningkatan pengetahuan, tetapi lebih jauh ke sikap dan perilakunya (Ambarwati, 2020) (Pratiwi \& Basuki, 2012).

Berdasarkan penelitian yang dilakukan, diketahui bahwa sebagian besar (62\%) ibu hamil memiliki pengetahuan yang baik, dan mayoritas responden dengan pengetahuan baik setuju/mendukung terhadap konseling dan tes HIVIAIDS secara sukarela (Titik Nuraeni, Nuke Devi Indrawati, 2010).

Tahun 2018 kabupaten Banyumas menduduki peringkat ketiga dengan jumlah kasus HIVIAIDS terbanyak di Provinsi Jawa tengah. Sejak bulan januari-juni tahun 2018 ditemukan kasus baru sebanyak 123 kasus. Sedangkan jumlah kasus komulatif sejak ditemukannya HIVIAIDS pada tahun 1993 hingga tahun 2018 sebanyak 1.146 kasus. Data kasus di Banyumas ini berasal dari laporan VCT (Voluntery Councelling and Test) dari Rumah sakit Prof. Margono Soekardjo dan RSUD Banyumas. Dari kasus HIVIAIDS yang ada di Kabupaten Banyumas ini, pemerintah kabupaten telah mengeluarkan kebijakan program pencegahan dan penanggulangan HIVIAIDS. Pemerintah Kabupaten Banyumas berharap seluruh penderita HIVIAIDS dapat memperoleh pelayanan sesuai standar (Banyumas, 2020).

Berdasarkan trend peningkatan kasus HIVIAIDS yang terjadi di Kabupaten Banyumas dan adanya program pencegahan dan penatalaksanaan kasus HIVIAIDS dari Dinas Kesehatan Kabupaten Banyumas, maka kegiatan penyebaran informasi untuk meningkatkan pengetahuan tentang HIVIAIDS merupakan prioritas program.

Dalam aktivitas pencegahan dan penagguangan HIVIAIDS diperlukan strategi komunikasi. Karena strategi komunikasi merupakan salah satu aspek keberhasilan program pencegahan dan penanggulangan HIVIAIDS. Strategi komunikasi ini dimaksudkan agar komunikasi yang dilakukan dapat berjalan dengan efektif, tepat sasaran dan memiliki dampak positif bagi penanggulangan HIVIAIDS. komunikasi yang efektif dapat menimbulkan lima hal yaitu pengertian, kesenangan, pengaruh pada sikap, hubungan yang makin baik dan tindakan (Lestari \& Nurhayat, 2015).

Strategi komunikasi yang dilakukan oleh Pemerintah Kabupaten Banyumas belum memberikan pengaruh pada paradigma dikalangan masyarakat tentang HIVIAIDS. Sehingga tujuan dilakukannya pelatihan pada mitra adalah sebagai upaya meningkatkan kemampuan tehnik komunikasi tentang HIVIAIDS pada mitra dan penyebaran leaflet tentang pencegahan dan penatalaksanaan HIVIAIDS pada mitra.

\section{METODE}

Mitra pada pelatihan teknik komunikasi merupakan kader 'Asiyiah Purwokerto Selatan. Pelaksanaan pengabdian bertempat di SMP Muhammadiyah 1 Purwokerto dengan jumlah peserta 20 orang. Metode yang digunakan dalam pelatihan meliputi ceramah, tanya jawab, diskusi dan penayangan video. Tahapan kegiatan dimulai dengan icebraking, 
pre test, penyampaian materi, praktik ketrampilan dan ditutup dengan post test (Riani \& Ambarwati, 2020).

Evaluasi kegiatan dilakukan untuk mengukur tingkat keberhasilan dari program yang ditawarkan, yang meliputi evaluasi pengetahuan dan pemahaman sasaran pemahaman (knowledge) dilakukan dengan cara pre test dan post test kepada seluruh peserta pelatihan. Aspek Skill ( ketrampilan ) yang dinilai adalah ketrampilan mitra dalam mempraktikkan tekhnik komunikasi.

\section{HASIL DAN PEMBAHASAN}

\section{Pelatihan Teknik Komunikasi HIVIAIDS}

Media yang digunakan dalam penyuluhan berupa leaflet dan materi dalam bentuk power point.

Selama pemberian materi berlangsung, peserta aktif berpartisipasi dan bertanya halhal yang tidak dipahami. Diskusi dan tanya jawab didampingi oleh Tim pengabdian.

Kegiatan pelatihan tehnik komunikasi kasus HIV-AIDS terdiri dari tahapan sebagai berikut:

\section{a. Pre Test}

Kegiatan ini dilaksanakan dengan tujuan untuk mengetahui kemampuan peserta sebelum mengikuti kegiatan. Peserta diberikan soal terkait HIV-AIDS. Alokasi waktu yang diberikan adalah 15 menit.

b. Penyampaian Materi

Materi yang disampaikan tentangtehnik komunikasi. Alokasi waktu yang diberikan adalah 45 menit, dilanjutkan dengan tanya jawab.

c. Focus Group Discussion (FGD)

Peserta dibagi dalam 3 kelompok kecil dan dipandu oleh tim. FGD dilakukan dengan tahapan penmbacaan sekenario kasus HIV-AIDS dan dilanjutkan dengan diskusi. Target dalam FGD ini adalah adanya solusi kasus dalam sekenario melalui tehnik komunikasi yang baik.

d. Role Play \& Simulasi

Masing-masing kelompok melakukan simulasi berdasarkan sekenario kasus HIV-AIDS yang telah didiskusikan melalui FGD. Peserta antusias dalam membawakan peran masing-masing.

e. Post Test

Post test dilaksanakan di akhir kegiatan untuk mengetahui kemampuan peserta di akhir kegiatan. Hasil post test menunjukan adanya peningkatan pengetahuan peserta dengan nilai rata rata 67 menjadi 94,5 atau terjadi peningkatan sebesar $40 \%$

\section{SIMPULAN}

Peningkatan pengetahuan kader 'Aisyiyah Cabang purwokerto Selatan pencegahan dan penatalaksanaan kasus HIVIAIDS.

Peningkatan kemampuan tehnik komunikasi tentang HIVIAIDS

\section{DAFTAR RUJUKAN}

Ambarwati, E. N. R. D. (2020). Persepsi Ibu Hamil Dalam Pemeriksaan HIVIAIDS Di banyumas. Journal of Chemical Information and Modeling, 6(1), 12-15. https://jurnal.polibara.ac.id/index.php/ medsains/article/view/121/94

Banyumas, D. K. K. (2020). Profil Kesehatan Tahun 2019. In Journal of Chemical Information and Modeling (Vol. 53, Issue 9).

Kemenkes RI. (2018). InfoDatin-HIV-AIDS2018.pdf (p. 12).

Lestari, Y., \& Nurhayat, I. (2015). Strategi Komunikasi Sosialisasi Pengetahuan Dasar Komprehensif HIVIAIDS. Komunikasi, IX(02), 13-28. https://journal.trunojoyo.ac.id/komunika si/article/view/1833/1516

Pratiwi, N., \& Basuki, H. (2012). Hubungan Karakteristik Remaja Terkait Risiko Penularan HIV-AIDS Dan Perilaku Seks Tidak Aman Di Indonesia. Buletin Penelitian Sistem Kesehatan, 14(4 Okt), 1-12. https://doi.org/10.22435/bpsk.v14i4

Riani, E. N., \& Ambarwati, D. (2020). Early Detection Kanker Serviks Sebagai Upaya Peningkatan Derajat Hidup Perempuan. SELAPARANG Jurnal Pengabdian Masyarakat Berkemajuan, 3(2), 144. https://doi.org/10.31764/jpmb.v3i2.188 3

Riani, E. N., Shaluhiyah, Z., \& Widagdo, L. (2016). Petugas Lapangan Sebagai Ujung Tombak Jumlah Pengunjung Klinik VCT. Jurnal Promosi Kesehatan Indonesia; Volume 9, No. 2, Agustus 2014DO - 10.14710/Jpki.9.2.152-161. https://ejournal.undip.ac.id/index.php/jp ki/article/view/12730

Siswanto, S. B. S. (2010). Pengetahuan HIV Dan AIDS Pada Remaja Di Inonesia (Analisis Data Riskesdar 2010) (p. 1). https://media.neliti.com/media/publicati ons/105651-ID-pengetahuan-hiv-danaids-pada-remaja-di.pdf

Tengah, D. K. P. J. (2019). Profil Kesehatan Provinsi Jawa Tengah Tahun 2018. http://dinkesjatengprov.go.id/v2018/do kumen/profil_2018/mobile/index.html 
Titik Nuraeni, Nuke Devi Indrawati, A. R. (2010). Hubungan Pengetahuan lbu Hamil Tentang HIVIAIDS Dan VCT Dengan Sikap Terhadap Konseling Dan tes HIVIAIDS Secara Sukarela Di Puskesmas Karangdoro Semarang. Jurnal Kebidanan. https://core.ac.uk/download/pdf/23403 6723.pdf 